\title{
Sedimentary response to sea ice and atmospheric variability over the instrumental period off Adélie Land, East Antarctica
}

\author{
Philippine Campagne ${ }^{1,2,3,4}$, Xavier Crosta ${ }^{1}$, Sabine Schmidt ${ }^{1}$, Marie Noëlle Houssais ${ }^{2}$, Olivier Ther ${ }^{1}$, and \\ Guillaume Massé 2,3 $^{2,3}$ \\ ${ }^{1}$ EPOC, UMR CNRS 5805, Université de Bordeaux, Allée Geoffroy St Hilaire, 33615 Pessac, France \\ ${ }^{2}$ LOCEAN, UMR CNRS/UPCM/IRD/MNHN 7159, Université Pierre et Marie Curie, 4 Place Jussieu, 75252 Paris, France \\ ${ }^{3}$ TAKUVIK, UMI 3376 UL/CNRS, Département de Biologie, Université Laval, G1V 0A6 Quebec (Quebec), Canada \\ ${ }^{4}$ Québec-Océan, Université Laval, 1045 Avenue de la Médecine, G1V 0A6 Quebec (Quebec), Canada
}

Correspondence to: Philippine Campagne (p.campagne@epoc.u-bordeaux1.fr)

Received: 27 November 2015 - Published in Biogeosciences Discuss.: 25 January 2016

Revised: 16 June 2016 - Accepted: 20 June 2016 - Published: 25 July 2016

\begin{abstract}
Diatoms account for a large proportion of primary productivity in Antarctic coastal and continental shelf zones. Diatoms, which have been used for a long time to infer past sea surface conditions in the Southern Ocean, have recently been associated with diatom-specific biomarkers (highly branched isoprenoids, HBI). Our study is one of the few sedimentary research projects on diatom ecology and associated biomarkers in the Antarctic seasonal sea ice zone. To date, the Adélie Land region has received little attention, despite evidence for the presence of high accumulation of laminated sediment, allowing for finer climate reconstructions and sedimentary process studies. Here we provide a sequence of seasonally to annually laminated diatomaceous sediment from a $72.5 \mathrm{~cm}$ interface core retrieved on the continental shelf off Adélie Land, covering the 1970-2010 CE period. Investigations through statistical analyses of diatom communities, diatom-specific biomarkers and major element abundances document the relationships between these proxies at an unprecedented resolution. Additionally, comparison of sedimentary records to meteorological data monitored by automatic weather station and satellite derived sea ice concentrations help to refine the relationships between our proxies and environmental conditions over the last decades. Our results suggest a coupled interaction of the atmospheric and sea surface variability on sea ice seasonality, which acts as the proximal forcing of siliceous productivity at that scale.
\end{abstract}

\section{Introduction}

Diatoms have been used for a long time to infer past sea surface conditions in the Southern Ocean on the basis of largescale ecological studies from the plankton (e.g. Hasle, 1969) and surface sediments (DeFelice and Wise, 1981; Zielinski et al., 1997; Armand et al., 2005; Crosta et al., 2005). However, little is known about diatom ecology in the seasonal sea ice zone and especially in the coastal and continental shelf zone (CCSZ) off East Antarctica. The Adélie Land region has especially received little attention despite evidence about high accumulation sites of laminated sediments (e.g. Escutia et al., 2010). A very limited number of ecological studies have been performed at the species or species group level in the plankton (Beans et al., 2008; Riaux-Gobin et al., 2013) or sediments (Leventer et al., 1992; Maddison et al., 2006, 2012; Denis et al., 2006), and even fewer studies have investigated their relationships with local or regional environmental conditions. As a result, diatom-based palaeoenvironmental reconstructions for this area are derived from large-scale studies and do not take into account the regional specificities. The Adélie Land region is of further interest due to the presence of coastal polynyas, in the vicinity of the Dumont d'Urville station (DDU) and the Mertz Glacier (MG), which are biologically very productive and because it is where intense sea ice formation during winter leads to a large volume of dense water production (Arrigo and van Dijken, 2003; Sambrotto et al., 2003; Lacarra et al., 2014), fuelling the global circulation (Rintoul et al., 1998). 
Investigations of diatom communities, diatom-specific biomarkers and major element concentrations at high resolution along a $72.5 \mathrm{~cm}$ long interface core retrieved in the Dumont d'Urville Trough (DDUT) allowed documentation of the relationships between these proxies. Additionally, the comparison of our proxy records to meteorological data inferred from DDU automatic weather station and satellite derived sea ice concentrations helped to determine the relationships between environmental conditions and proxy data; consequently the sedimentary response to atmospheric and sea surface changes. Here, we refine our knowledge of diatom ecology at the regional scale and propose a robust tool to infer past sea surface conditions off Wilkes Land.

\section{Environmental settings}

\subsection{Geographic features}

The DDUT (Fig. 1b), located along the Adélie Land on the East Antarctic margin, is composed of several glacial depressions. These topographic features, up to $1000 \mathrm{~m}$ deep, act as traps for sedimentary material (primary production and terrigenous particles) settling out from surface waters. The trough runs from the front of the Zélée and Astrolabe glaciers to the continental shelf break along a SE-NW orientation and is bordered on its eastern side by the Dumont D'Urville bank (DDU bank; Fig. 1b), which culminates at $200 \mathrm{~m}$ below sea level and limits exchanges with the Adélie Depression. On the western side, the DDUT is flanked by the Dibble Bank where the Dibble Ice Tongue perdures during summer as a seaward protrusion.

\subsection{Water masses}

The Adélie Land is influenced by several water masses and currents (Rintoul et al., 1998; Williams and Bindoff, 2003; Williams et al., 2008). The wind-driven East Wind Drift flows westward at the surface and transports Antarctic Surface water that constitutes the summer subsurface water mass on the continental shelf. The Circumpolar Deep Water upwells near the Antarctic Divergence and intrudes onto the plateau during summer. The High-Salinity Shelf Water originates from brine rejections during winter sea ice formation and from the winter cooling of the Circumpolar Deep Water (Fig. 1). The High-Salinity Shelf Water flows northward at the sea floor as part of the dense shelf waters, namely Adélie Land Bottom Water, which represents a major contributor to Antarctic Bottom Water (Rintoul et al., 1998; Jacobs et al., 2004; Meredith et al., 2013).

\subsection{Wind conditions}

The Adélie Land coast experiences the windiest conditions ever recorded on Earth through the presence of intense katabatic winds (Périard and Pettré, 1993) that are funnelled
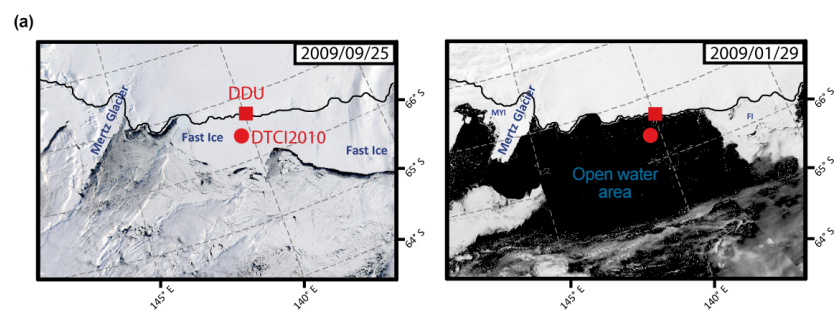

(b)

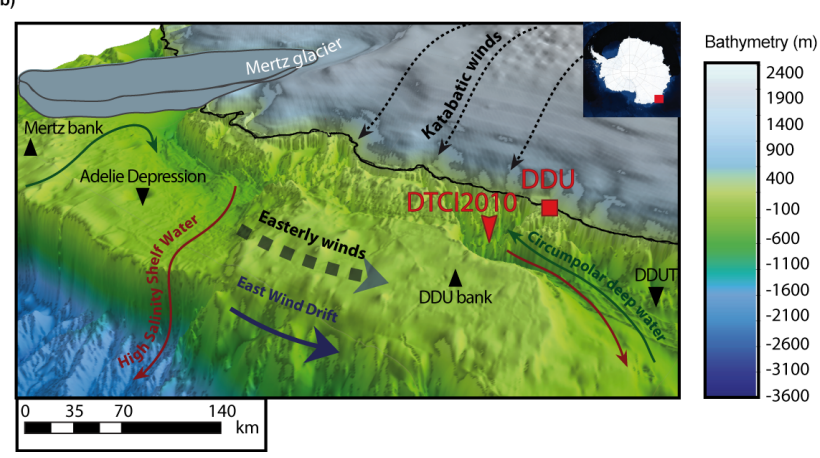

Figure 1. Study area. (a) Modis satellite images of Adélie Land, showing mean sea ice conditions from early spring to summer in the region, the location of sediment core DTCI2010 and the French research station Dumont D'Urville (DDU). (b) Map of the study area showing the location of sediment core DTCI2010 in the Dumont D'Urville Trough (DDUT), the main glacial and topographic features, the principal water masses (solid lines) and the main wind streams (dashed lines).

by narrow glacial valleys close to the shoreline (Wendler et al., 1997). Although relatively strong winds $\left(>10 \mathrm{~m} \mathrm{~s}^{-1}\right)$ blow widely between 65 and $225^{\circ}$ at DDU, the station is characterized by a dominant and recurrent katabatic wind from $140-180^{\circ}$ (SE) coinciding with maximum wind speeds $\left(>25 \mathrm{~m} \mathrm{~s}^{-1}\right.$ ) (Adolph and Wendler, 1995; Köning-Langlo et al., 1998). Such winds support the annual occurrence of polynyas in the region, such as the DDU Polynya (DDUP; $66.11^{\circ} \mathrm{S}-139.31^{\circ} \mathrm{E}$ ), where important sea ice production occurs (Adolphs and Wendler, 1995; Massom et al., 1998; Arrigo and van Dijken, 2003).

\subsection{Sea ice conditions}

In general, the sea ice melts every year between November and December and reforms in February-March, with sea ice concentrations greater than $80 \%$ in winter and dropping below $20 \%$ in summer (Arrigo and van Dijken, 2003). Both pack ice and fast ice are observed in the DDUT. Pack ice melts every year while fast ice may persist during summer months (Fig. 1a; Massom et al., 2003, 2009; Smith et al., 2011; Wang et al., 2014). At its maximum extent, fast ice develops $\sim 100 \mathrm{~km}$ offshore between the Dibble Ice Tongue and the Adélie Bank (Fig. 1a; Massom et al., 2009; Smith et al., 2011). From the early spring to autumn, unstable fast ice conditions, characterized by several fast ice breakouts and re- 
formations as a result of lack of anchor points, generally occur in the DDUT (Massom et al., 2009; Smith et al., 2011), whereas fast ice persists later in the season over the banks. A key factor of the formation, recurrence and persistence of these fast ice buttresses are the numerous grounded small icebergs on the Adélie and Dibble banks, which trap the passing pack ice and act as anchor points for fast ice formation (Massom et al., 2001; Giles et al., 2008; Smith et al., 2011), growing two ice promontories on either side of the core site. The presence of fast ice buttresses is therefore closely associated with the intense sea ice formation in the Mertz Glacier polynya and westward advection within the East Wind Drift (Fig. 1b; Massom et al., 2009).

\section{Material and Methods}

\subsection{Core description and ${ }^{210} \mathrm{~Pb}$ chronology}

A $72.5 \mathrm{~cm}$ long interface core, DTCI2010, was retrieved aboard the R/V Astrolabe $\left(66^{\circ} 24.68^{\prime} \mathrm{S} ; 140^{\circ} 26.67^{\prime} \mathrm{E} ; 1010\right.$ $\mathrm{m}$ water depth) during the 2010 ALBION-HOLOCLIP cruise. Positive X-ray images performed on the SCOPIX image-processing tool (Migeon et al., 1999) gave detailed information about sediment density and structure. SCOPIX images revealed laminations along the entire sedimentary section. The core was sampled continuously at $0.5 \mathrm{~cm}$ resolution and its chronological framework was determined based on ${ }^{210} \mathrm{~Pb}$ excess $\left({ }^{210} \mathrm{~Pb}_{\mathrm{xs}} ; T 1 / 2=22.3\right.$ years $)$. The activities of ${ }^{210} \mathrm{~Pb}$ and ${ }^{226} \mathrm{Ra}$ were measured on dried sediments by non-destructive gamma spectrometry using a well-type, high-efficiency low-background detector equipped with a Cryo-cycle (CANBERRA) (Schmidt and De Deckker, 2015). Activities are expressed in $\mathrm{mBqg}^{-1}$ and errors are based on $1 \mathrm{SD}$ counting statistics. ${ }^{210} \mathrm{~Pb}_{\mathrm{xs}}$ was determined by subtracting the activity supported by its parent isotope, ${ }^{226} \mathrm{Ra}$, from the total ${ }^{210} \mathrm{~Pb}$ activity in the sediment. In the interface core DTCI2010, there is a general downcore trend in decreasing ${ }^{210} \mathrm{~Pb}_{\mathrm{xs}}$ activities, from 242 to $74 \mathrm{mBq} \mathrm{g}^{-1}$, as expected, due to the decay of the unsupported ${ }^{210} \mathrm{~Pb}$ (Fig. 2). However, the observation of a layer where activities decrease slowly between 10 and $40 \mathrm{~cm}$ led us to retain the constant initial concentration model (CIC; Robbins and Edgington, $1975)$ to calculate the age $(t)$ of each measured horizon as $t=(1 / \lambda) \ln \left(A_{0} / A_{z}\right)$, where $t$ and $A_{z}$ are the age of the sediment and the excess ${ }^{210} \mathrm{~Pb}$ activity at the depth $z, A_{0}$ is the activity at the surface and $\lambda$ is the decay constant of ${ }^{210} \mathrm{~Pb}$. This choice is supported by the almost constant activities measured in the uppermost sediments of cores collected in $2003\left(240 \pm 13 \mathrm{mBqg}^{-1}\right.$; Massé et al., 2011) and 2011 (253 $\pm 13 \mathrm{mBqg}^{-1}$ in DTCI2011; Schmidt S., unpublished data). A second-order polynomial function was calculated from the $11^{210} \mathrm{~Pb}$ dates obtained over the entire core to build the age model (Fig. 2).

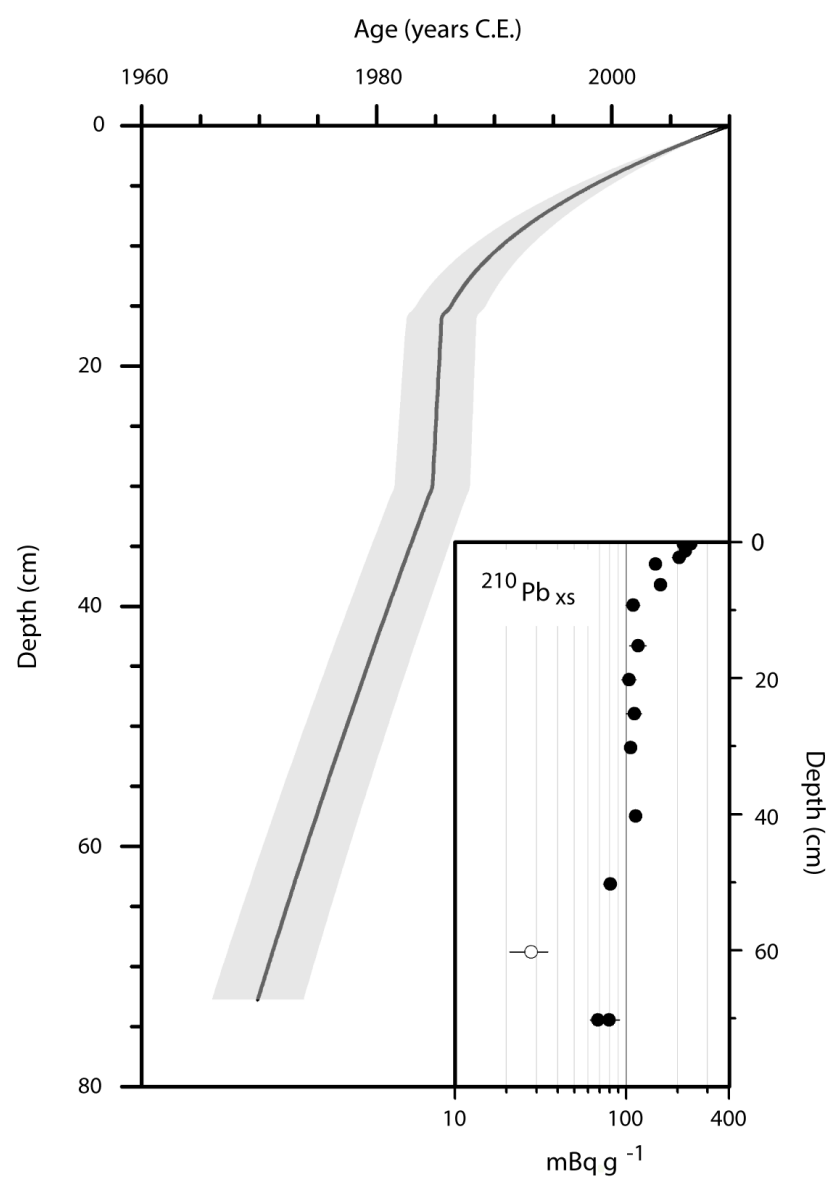

Figure 2. DTCI2010 chronology, based on ${ }^{210} \mathrm{~Pb}$ excess $\left({ }^{210} \mathrm{~Pb}\right.$ xs $)$ and associated age model errors (grey area). The inset corresponds to the downcore profile of ${ }^{210} \mathrm{~Pb}_{\mathrm{xs}}$ (error bars correspond to $1 \mathrm{SD}$ ).

\subsection{Sedimentary analyses}

\subsubsection{Diatoms}

Micropalaeontological analyses were performed according to the methodology described in Rathburn et al. (1997) at $\mathrm{a} \sim 0.25$-year resolution (every $0.5 \mathrm{~cm}$ ) in core DTCI2010. Counts were performed under a microscope Olympus BH-2 at a magnification of $\times 1000$. For each sample, 300-350 diatom valves were counted and data are presented as species relative abundances. Diatom identification was performed to the species or species group level following the taxonomical references detailed in Crosta et al. (2004) and the counting rules described in Crosta and Koç (2007). Sixty-two diatom species were identified in down-core assemblages, from which 24 presented abundances higher than $2 \%$ of the total diatom assemblages (Table $\mathrm{S} 1$ in Supplement). 


\subsubsection{Biomarker}

Few marine and freshwater diatoms belonging to the Haslea, Navicula, Pleurosigma and Rhizosolenia genera were recently found to be synthesizing highly branched isoprenoids (HBI) (Sinninghé Damsté et al., 2004; Massé et al., 2011). Recent studies have proposed the use of HBIs to reconstruct variations of Holocene Antarctic sea ice duration as a complementary approach to diatom counts (Collins et al., 2013; Campagne et al., 2015; Smik et al., 2016). Biomarker analysis followed the technique described by Massé et al. (2011) and were also performed at a $\sim 0.25$-year resolution (every $0.5 \mathrm{~cm}$ ) in core DTCI2010.

\subsubsection{XRF}

$\mathrm{X}$-Ray fluorescence (XRF) measurements were conducted on slab sections at a $2 \mathrm{~mm}$ resolution along the entire core using an AAVATECH XRF core scanner at two different tube voltages (10 and $30 \mathrm{keV}$ ), allowing for the determination of major elements associated with the detrital (Rubidium $[\mathrm{Rb}]$ ) and terrigenous fractions (Zirconium [Zr] and Titanium [Ti]). More details about the protocol can be found in Fleury et al. (2015).

\subsection{Instrumental data}

\subsubsection{Atmospheric data}

Daily measurements of wind direction (from 0 to $360^{\circ}$ ), velocity $\left(\mathrm{m} \mathrm{s}^{-1}\right)$ and temperature $\left({ }^{\circ} \mathrm{C}\right)$ for the time period 1956-2011 were obtained from the METEO France publithèque. The data set is based on the automatic weather station at the DDU French station $\left(66.7^{\circ} \mathrm{S}, 140^{\circ} \mathrm{E}\right.$; Wendler et al., 1997), $30 \mathrm{~km}$ from the core site. The data set provides monthly statistics based on 6-hourly in situ observations at $10 \mathrm{~m}$. Wendler et al. (1997) showed that from Penguin Point (east of the Mertz Glacier) to DDU stations, meteorological parameters displayed similar variations, leading to the conclusion that measurements from the automatic weather station were relatively robust. Wind direction represents the origin of the wind over $360^{\circ}$. Easterly, southerly, northerly and westerly wind components indicate the number of days between November and March during which the wind blows between 45 and $135^{\circ}, 135$ and $225^{\circ}, 315$ and $45^{\circ}$ and 225 and $315^{\circ}$ respectively. A ratio between easterly and southerly wind components (hereafter denoted by E/S), and a ratio between northerly and westerly wind components (hereafter denoted by N/W), were calculated and used to account for the dominant and secondary wind directions in the region according to the literature and observations (Note S2). Monthly anomalies are expressed relative to the mean value calculated for each month over the 1979-2009 period.

\subsubsection{Sea ice data}

Daily sea ice concentrations (SIC) for the time period 19782012 were obtained from the National Snow and Ice Data Center data repository. The data set is based on passive microwave observations from the Nimbus-7 SSMR (19781987) and DMSP SSM/I (1987-2007) and SSMIS (20072012) radiometers processed with the NASA Team algorithm (Cavalieri et al., 1995) at a spatial resolution of $25 \times 25 \mathrm{~km}$. Averaged sea ice concentrations (SIC) were calculated over the core site in the central part of the DDUT (Fig. S1). The sea ice retreat date was determined arbitrarily as the $\mathrm{Ju}$ lian day when the SIC (7-day average) dropped below $40 \%$, while the sea ice advance corresponds to the day when SIC increased to above $40 \%$. The duration of the ice-free season corresponds to the number of days per year during which SIC $<40 \%$. Monthly anomalies are expressed relative to the mean value calculated for each month over the 1979-2009 period.

\subsection{Statistical analyses}

Statistical analyses were run using the statistical software XLStat (Addinsoft). Principal component analyses (PCA) and Pearson correlation tests (significance level $\alpha=0.05$ ) were performed on all 62 diatom species including the species accounting for less than $1 \%$ of the total diatom assemblage (Table S1 in Supplement), two diatom-specific biomarkers along with their associated ratio and three major elements. They include a ratio to (1) determine the relationships between species and identify potential diatom cluster (in order to increase the statistical weight of minor species) and (2) investigate the relationships between the different proxies in our study. Complete statistical analyses are presented in Note S1 (Fig. S2; Table S2), and allowed to identify the sedimentary proxies that are significant in our study area (presented in Sect. 4), in terms of abundances and ecological preferences. Additionally in Note S2 (Fig. S3; Table S3), PCA and the Pearson correlation test were performed on seasonally averaged meteorological and satellite data to support the few previous oceanographic and atmospheric observations about climate forcing and their environmental response in the area. This work constituted a basis to a final PCA (presented in Sect. 5) between annually averaged meteorological data and significant sedimentary proxies interpolated at 1 year to determine, through the sedimentary response, how the preserved signal responds to local environmental parameters. Although the standardization of our data partially hide the variability of our sedimentary signals (Fig. S4), the main characteristics are preserved and allow for interannual comparisons. 


\section{Results}

\subsection{Sedimentary signals}

The main diatom species and species groups identified in core DTCI2010 (Note S1) are Fragilariopsis cylindrus, Thalassiosira antartica, Porosira glacialis and Porosira pseudodenticulata (hereafter denoted by Porosira gp.; Note S1), Fragilariopsis kerguelensis, large centric species (denoted by Open Water gp.; Note S1), Rhizosolenia species (denoted by Rhizosolenia gp.) and Chaetoceros Hyalochaete resting spores (denoted by CRS). These diatom groups are presented along with diunsaturated HBI isomers [HBI:2], triunsaturated HBI isomers [HBI:3] and their respective ratio, titanium (Ti) contents and zirconium vs. rubidium $(\mathrm{Zr} / \mathrm{Rb})$ that constitute the main relevant geochemical proxies identified in our study area (Note S1). Other diatom proxies such as the Banquisia gp., Fragilariopsis obliquecostata, Fragilariopsis curta, Eucampia antarctica, the Fragilariopsis summer gp., the Thalassiothrix gp., Fragilariopsis rhombica, Chaetoceros Phaeoceros, and the Benthic gp., sometimes used in the literature to infer past sea ice conditions, are here not significant in terms of population and/or relevant in term of statistical relationships to other proxies and environmental parameters. They are discussed in Note S1.

The highest abundances of $F$. cylindrus in sediments are observed during the 1972-1979, 1983-1984, 1996-1998 and 2002-2003 CE periods. [HBI:2] concentrations present a similar pluri-decadal pattern to $F$. cylindrus. However, pluri-annual variations have an opposite pattern, with higher concentrations in 1971-1978, 1982, 1985-1986, 1989, 1995-2002 and since 2006CE (Fig. 3a). The CRS and $\mathrm{Zr} / \mathrm{Rb}$ exhibit contrasting trends during the 1970s to the mid-1980s, with decreasing CRS relative abundances and increasing $\mathrm{Zr} / \mathrm{Rb}$ values during the 1973-1976 and 19771978 CE periods. They are then relatively in phase with concomitant increasing values in 1984/1985-1987 and in 19891995 CE. The Open Water gp. and F. kerguelensis records display similar patterns, increasing in 1972-1977, 19801986, 1995-2001 and 2007 CE. In the same way, the $\mathrm{Ti}$ contents increase in 1975-1978, 1985-1987, 1996-2001 and 2008-2010 CE. [HBI:3] and the Rhizosolenia gp. exhibit a similar pattern with high values in 1973-1975 CE and moderate values in $\sim 1978-1980,1983-1985$ and 1995$2001 \mathrm{CE}$. Thalassiosira antarctica increased slightly over the periods 1976-1978 and 1982-1985 and reached highest values between 2000 and 2010 CE. The Porosira gp. increased slightly over the 1980-1986 CE and large increases occurred around the $\sim 2000$ and 2007 CE periods.

\section{Environmental parameters}

Atmospheric data indicate the increasing occurrence of easterly winds from spring to autumn (Fig. 3b) during the 1970-
1975 CE, 1983-1984 CE and between 1997 and $2007 \mathrm{CE}$ periods (Fig. 3b). At the opposite, southerly winds dominate during the 1976-1982, 1985-1996 CE periods and since 2008 CE (Fig. 3b). The increasing occurrence of northerly winds from spring to autumn characterizes the 1971-1975, 1979-1980, 1984, 1992 CE and 1996-2001 CE periods, and more westerly winds occur between 1975-1979, 1981-1982, 1985-1991, 1993-1996, 2000 and since 2002 CE (Fig. 3b). Analysis of the satellite data reveals the presence of heavier sea ice conditions in the area during spring, summer and autumn in the 1979-1981, 1990-1998 and 2001-2004 CE periods (Fig. 3b), which coincide with delayed sea ice retreat in spring and summer. In contrast, earlier open conditions in spring occur between $\sim 1981$ and 1988, $\sim 1994, \sim 1998$ and 2001 and $\sim 2005-2007$ CE (Fig. 3b). Delayed sea ice advance in autumn characterizes the 1980s and the $2002 \mathrm{CE}$ periods, while earlier sea ice closing occurs between 1989 and 2001 and since 2003 CE (Fig. 3b).

\section{Discussion}

Below, we first discuss the significance, behaviour and relationships between the relevant proxies at the DDUT site over the last 40 years. Secondly, we statistically confront 40 years of instrumental records to our sedimentary signals, which are commonly used for palaeoclimate reconstructions to refine our understanding of their ecological preferences or environmental significance in the CCSZ at the regional scale of Adélie Land .

\subsection{Sedimentary signals off Adélie Land over the instrumental period}

\subsubsection{Sea ice proxies}

High occurrences of $F$. cylindrus populations and [HBI:2] in high southern latitude water column and sediments, including our study area, characterize spring sea ice occurrence (Kang and Fryxell, 1992; Armand et al., 2005; Massé et al., 2011; Smik et al., 2016; Table 1; Note S1). High abundances of these proxies were used in Holocene sediments to track consolidated sea ice conditions lasting in summer (Leventer et al., 1993; Campagne et al., 2015). Our results indicate that intervals characterized by heavier sea ice conditions in the area from spring to autumn (Fig. 3b) broadly coincide with those characterized by higher abundances of $F$. cylindrus (Fig. 3a). However, changes in sea ice concentration do not satisfactorily explain $F$. cylindrus variability during the last 40 years. Additionally, F. cylindrus abundances present a weak agreement with the timing of the sea ice retreat (Fig. 3). Conversely, a relation is observed between $F$. cylindrus abundances and wind origin, whereby increasing occurrences of relatively weak northerly winds coincide with higher abundances of the species (Fig. 3). As observed for F. cylindrus, changes in [HBI:2] concentration over the last 40 years do 
(a)

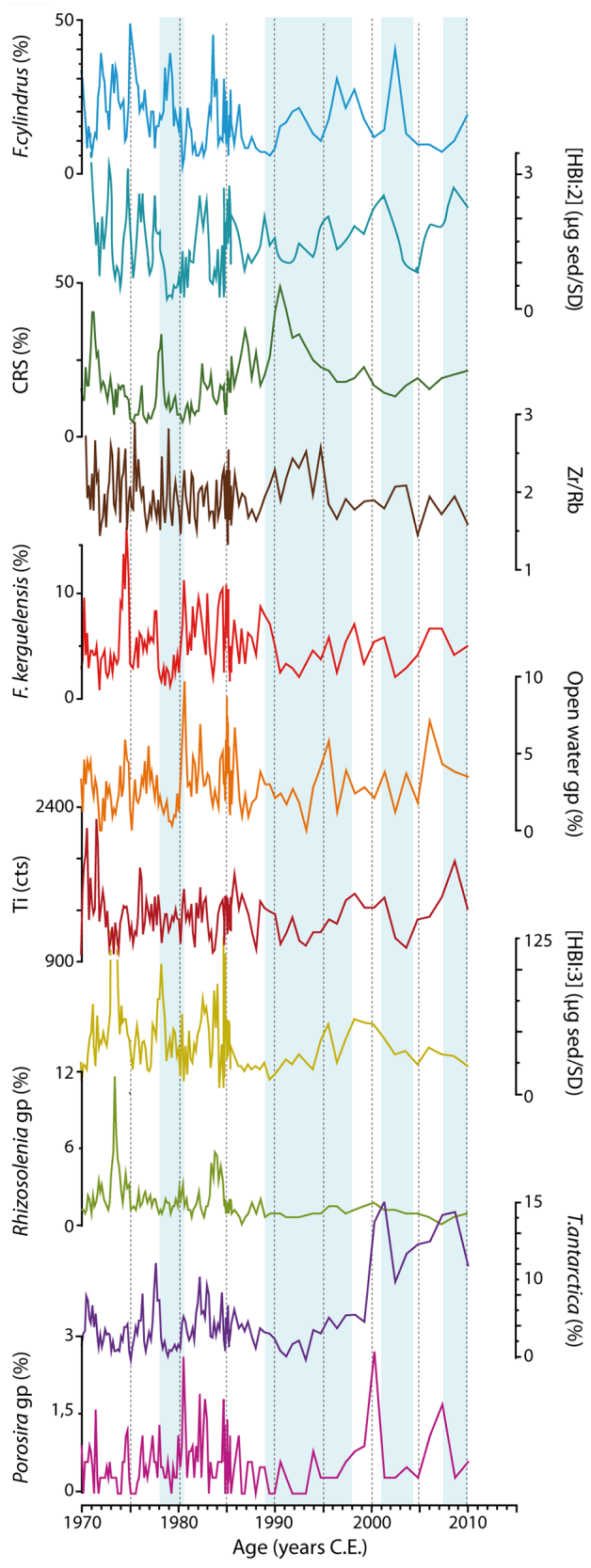

(b)

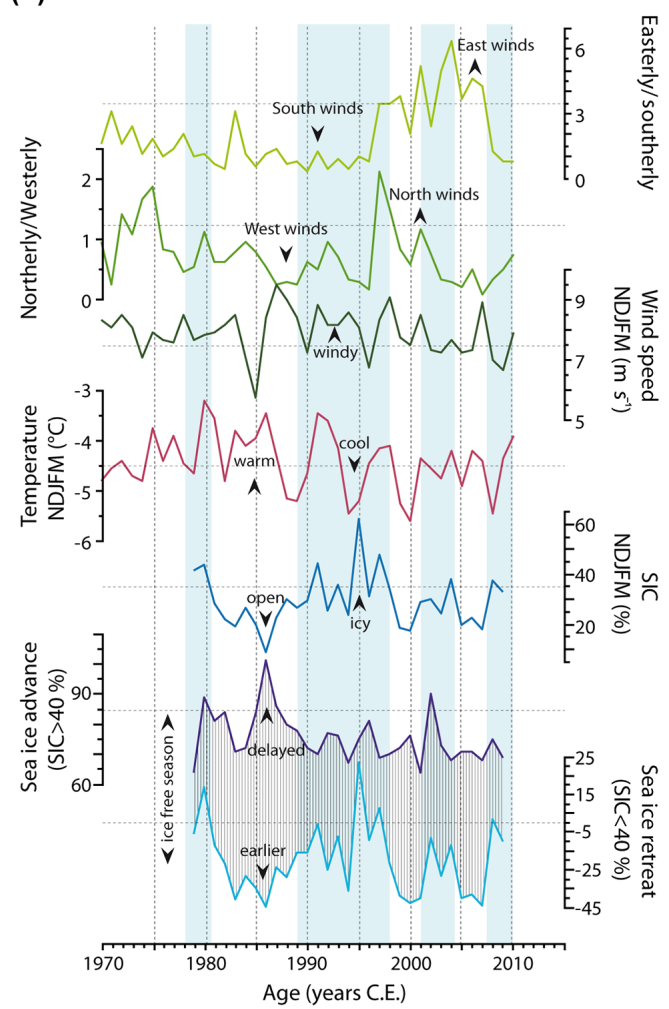

Figure 3. (a) Raw sedimentary records from DTCI2010 interface core over the 1970-2010 period. The blue shading indicates periods marked by increasing monitored sea ice concentration at the core site. (b) Meteorological parameters and climate index over the 1970-2010 period. Daily meteorological parameters were averaged over the November to March period. Blue shaded areas mark increases of SIC. Supplementary core data are available at: https://doi.org/10.1594/PANGAEA.863075.

not closely follow SIC variations nor seasonal sea ice dynamics (Fig. 3). Rather, high concentrations of this biomarker cooccur with more westerly winds (Fig. 3).

Thalassiosira antarctica and the Porosira gp. were found to share similar seasonal occurrence in autumn, although it has been suggested that $P$. glacialis prefers slightly colder and icier conditions (Pike et al., 2009; Table 1; Note S1).
Thalassiosira antarctica and the Porosira gp. have thus been interpreted in Holocene sediments to indicate a late summer/autumn rapid deposition, linked to early sea ice return (Denis et al., 2006; Maddison et al., 2006, 2012). As already observed for previous sea-ice-related proxies, the distribution of autumnal bloom species does not closely follow SIC variations in our study area (Fig. 3). However, our results suggest 
Table 1. Summary of the relationships between sedimentary proxies and environmental conditions.

\begin{tabular}{|c|c|c|}
\hline $\begin{array}{l}\text { Proxy/group identified in core } \\
\text { DTCI2010 }\end{array}$ & Known ecology (literature) & Environmental relationships off Adélie land \\
\hline F. cylindrus & $\begin{array}{l}\text { Spring sea-ice-covered/sea-ice } \\
\text {-stratified waters }\end{array}$ & $\begin{array}{l}\text { Compacted pack ice in spring by northerly } \\
\text { winds ("warm" sea ice), sea-ice } \\
\text {-stratified waters }\end{array}$ \\
\hline [HBI:2], [HBI:2] / [HBI:3] & Spring sea ice environment & $\begin{array}{l}\text { Compacted pack ice or fast ice in spring by } \\
\text { westerly winds (cold sea ice) }\end{array}$ \\
\hline $\begin{array}{l}\text { Banquisia gp. } \\
\text { (N. directa } N . \text { glaciei, } \\
\text { Synedra } \text { spp., } \\
\text { Ephemera } \text { spp.) }\end{array}$ & Spring sea ice conditions & No clear pattern \\
\hline F. obliquecostata & $\begin{array}{l}\text { Surface melt pools, sea-ice-covered } \\
\text { waters in summer }\end{array}$ & No clear pattern \\
\hline E. antarctica & $\begin{array}{l}\text { Ubiquist, open conditions, } \\
\text { melting glacial ice }\end{array}$ & $\begin{array}{l}\text { Onshore winds increase spring-summer sea ice } \\
\text { (short ice-free season, delayed sea ice retreat) }\end{array}$ \\
\hline $\begin{array}{l}\text { Fragilariopsis summer gp. } \\
\text { (F. ritscheri, F. sublinearis) }\end{array}$ & $\begin{array}{l}\text { Summer sea ice edge environment, } \\
\text { melted waters }\end{array}$ & No clear pattern \\
\hline T. antarctica & $\begin{array}{l}\text { Open water conditions in } \\
\text { summer-autumn, slush and } \\
\text { wave-exposed shore ice environment }\end{array}$ & $\begin{array}{l}\text { Summer open water conditions but icy autumn } \\
\text { conditions (early sea ice advance) induced by } \\
\text { easterly winds }\end{array}$ \\
\hline $\begin{array}{l}\text { Porosira gp. }(P . \text { glacialis, } \\
\text { P. pseudodenticulata })\end{array}$ & $\begin{array}{l}\text { Relative open water conditions in } \\
\text { summer, slush and wave-exposed shore } \\
\text { ice environment, icy autumn and early } \\
\text { sea ice advance }\end{array}$ & $\begin{array}{l}\text { Summer open water conditions but icy autumn } \\
\text { conditions (early sea ice advance) induced by } \\
\text { easterly winds }\end{array}$ \\
\hline F. kerguelensis & $\begin{array}{l}\text { Open water, ice-free conditions } \\
\text { during summer }\end{array}$ & $\begin{array}{l}\text { Summer open water conditions (early sea ice re- } \\
\text { treat, long ice-free season) induced } \\
\text { by easterly winds }\end{array}$ \\
\hline $\begin{array}{l}\text { Open water gp. (T. lentiginosa, } \\
\text { T. oliverana, T. trifulta, } \\
\text { T. gracilis, T. tumida, } \\
\text { Coscinodiscus spp., } \\
\text { A. actinochilus, } \\
\text { S. microtrias) }\end{array}$ & $\begin{array}{l}\text { Open water, ice-free conditions } \\
\text { during summer }\end{array}$ & $\begin{array}{l}\text { Summer open water conditions (early sea ice re- } \\
\text { treat, long ice-free season) induced } \\
\text { by easterly winds }\end{array}$ \\
\hline [HBI:3] & $\begin{array}{l}\text { Marginal ice zone, open water, ice-free } \\
\text { conditions during summer }\end{array}$ & $\begin{array}{l}\text { Summer open water conditions (early sea ice re- } \\
\text { treat) induced by easterly to northerly winds }\end{array}$ \\
\hline $\begin{array}{l}\text { Rhizosolenia } \text { gp. } \\
\text { (Rhizolenia } \text { spp., } \\
\text { R. antennata semispina, } \\
\text { Proboscia } \text { spp., P. truncata } \\
\text { and } P \text {. inermis) }\end{array}$ & $\begin{array}{l}\text { Open conditions in summer-autumn, } \\
\text { stratified oligotrophic waters }\end{array}$ & $\begin{array}{l}\text { No clear trend with sea ice conditions, stable } \\
\text { summer surface waters induced by northerly } \\
\text { winds }\end{array}$ \\
\hline $\begin{array}{l}\text { Thalassiotrix } \mathrm{gp} . \\
\text { (Tx. antarctica, } T \text {. reinboldii) }\end{array}$ & $\begin{array}{l}\text { Open conditions in autumn, highly } \\
\text { stable and nutrient-poor water column }\end{array}$ & $\begin{array}{l}\text { Summer open water conditions (early sea ice re- } \\
\text { treat, long ice-free season) induced } \\
\text { by easterly winds }\end{array}$ \\
\hline F. rhombica & $\begin{array}{l}\text { Unconsolidated sea ice in spring, } \\
\text { ice-free summer }\end{array}$ & $\begin{array}{l}\text { Warm conditions in spring-summer, delayed } \\
\text { ice-free season (late sea ice retreat and late sea } \\
\text { ice advance) }\end{array}$ \\
\hline $\mathrm{Ti}$ & $\begin{array}{l}\text { Summer open conditions favoring } \\
\text { glacial melting }\end{array}$ & $\begin{array}{l}\text { Rapid sea ice melting in spring, warm } \\
\text { open water conditions in summer induced by } \\
\text { northerly winds }\end{array}$ \\
\hline
\end{tabular}


Table 1. Continued.

\begin{tabular}{|c|c|c|}
\hline $\begin{array}{l}\text { Proxy/group identified in core } \\
\text { DTCI } 2010\end{array}$ & Known ecology (literature) & Environmental relationships off Adélie land \\
\hline $\mathrm{Zr} / \mathrm{Rb}$ & Polynya environment & $\begin{array}{l}\text { Coastal polynya activity under intense southerly } \\
\text { to south-easterly winds }\end{array}$ \\
\hline $\begin{array}{l}\text { CRS GP } \\
\text { (Chaetoceros Hyalochaetes } \\
\text { spp.) }\end{array}$ & $\begin{array}{l}\text { Rapid changes in stratification, } \\
\text { decreasing nutrient levels }\end{array}$ & $\begin{array}{l}\text { Stratification disruption at the MIZ or within } \\
\text { polynyas by katabatic wind pulses (high wind } \\
\text { speed) }\end{array}$ \\
\hline $\begin{array}{l}\text { Phaeoceros gp. } \\
\text { (C. Phaeoceros spp., } \\
\text { C. atlantica, } \\
\text { C. dichaeta) }\end{array}$ & Open water environment & No clear pattern \\
\hline $\begin{array}{l}\text { Benthic gp. } \\
\text { (Cocconeis spp., } \\
\text { Grammatophora spp., } \\
\text { Trachyneis spp., } \\
\text { Licmophora spp., } \\
\text { Melosira solenia, } \\
\text { Achnantes brevipes, } \\
\text { Amphora spp., } \\
\text { Diploneis spp., } \\
\text { Melosira adelia, } \\
\text { Pseudogomphonema spp., } \\
\text { O. weissflogii) }\end{array}$ & $\begin{array}{l}\text { Spring wind (storm)-induced } \\
\text { mixing conditions }\end{array}$ & No clear pattern \\
\hline $\begin{array}{l}\text { Corethron gp. } \\
\text { (C. criophilum, C. pennatum) }\end{array}$ & $\begin{array}{l}\text { Open ocean conditions, surface } \\
\text { mixed waters }\end{array}$ & No clear pattern \\
\hline
\end{tabular}

that the occurrence T. antarctica and the Porosira gp. should be linked to sea ice dynamics and wind variability, as a large increase of T. antarctica and Porosira gp. over the 2000s coincides with the earliest sea ice advance in the last 30 years and the prevalence of easterly winds (Fig. 3).

\subsubsection{Open ocean proxies}

Along with the Open Water gp., F. kerguelensis was found to dominate the summer and autumn laminae off East Antarctica and record a lengthening of the open water season and a warming of sea surface waters in summer (Denis et al., 2006; Maddison et al., 2006; Table 1; Note S1). In our data, open ocean proxies seem to follow regional sea ice conditions relatively well, regardless of the sea ice origin, structure and nature. Indeed, the Open Water gp. and F. kerguelensis present the highest relative abundances (Fig. 3a) during periods of low SIC, earlier sea ice retreat and enhanced ice-free season (Fig. 3b) and lowest values during periods of heavier sea ice conditions.

Ti content in sediment is an indicator of open water conditions (Table 1; Note S1), mainly reflecting variations in terrigenous delivery by glacial melting (Presti et al., 2003; Escutia et al., 2003). In our records, the Ti pattern is relatively coherent with the Open Ocean gp. and F. kergue- lensis records (Fig. 3a). The highest values generally occur during low SIC periods, long ice-free seasons and high temperatures such as during the 1980s. However, some discrepancies occurring as the highest sedimentary Ti values in 1970-1972 CE are concomitant to only a slight increase of open ocean proxies and no particular warming event in monitored temperatures (Fig. 3). This suggests that Ti content can be impacted by rapid deposition events that are independent of the length or the warmth of the ice-free season. Therefore, downcore differences between Ti and open ocean proxies may help to identify episodic processes such as local glacial discharge or ice rafted material derived from the Mertz Glacier Tongue basal melting (Maddison et al., 2006; Dinniman et al., 2012; Campagne et al., 2015).

[HBI:3] have been identified in water column phytoplankton (Massé et al., 2011; Table 1; Note S1), synthesized by the Rhizosolenoids (Sinninghé Damsté et al., 2004). The latter diatom group is generally associated with late summer season production and to long diatom productivity season, linked with turbulent open ocean conditions (Armand et al. 2005; Crosta et al. 2005; Beans et al., 2008; Note S1). In core DTCI2010, [HBI:3] and the Rhizosolenia gp. display similar patterns and present a strong relation with ice-free conditions (Fig. 3b). The maximum occurrence of [HBI:3] between the mid-1970s to the mid-1980s coincides well with positive 
temperature anomalies and lower wind speed anomalies at that time (Fig. 3b), arguing for a strong relationship between the biomarker development and surface conditions forced by atmospheric variability.

\subsubsection{Polynya activity proxies}

High percentages of CRS in Holocene sediments from Adélie and George V Land have been associated with strong siliceous productivity supported by melting ice-induced stratified surface waters and strong intermittent surface mixing conditions (Maddison et al., 2006; Table 1; Note S1). Off Adélie Land, vertical mixing, along with variations in bottom current velocities, were associated with enhanced polynya activity (Campagne et al., 2015; Table 1; Note S1) and were estimated from changes in sediment grain size inferred the $\mathrm{Zr} / \mathrm{Rb}$ ratio relative abundances. In core DTCI2010, CRS and $\mathrm{Zr} / \mathrm{Rb}$ exhibit contrasting trends during the 1970s to the mid-1980s, but have been relatively in phase over the last 20 years (Fig. 3a). $\mathrm{Zr} / \mathrm{Rb}$ follows SIC variations relatively well, whereas CRS relative abundances seem to follow spring sea ice dynamics (Fig. 3). Interestingly, a relationship is observed between CRS abundances and $\mathrm{Zr} / \mathrm{Rb}$ with wind pattern, as both proxies coincide well with the prevalence of southerly winds in our study area, e.g. between 1983 and 1996 CE (Fig. 3), arguing for a strong relationship between the polynya activity and atmospheric pattern variability.

\subsection{The coupled role of wind pattern and sea ice variability on sea surface productivity in Adélie Land}

PCA between seasonal atmospheric forcing and sea ice conditions over the core site (Note S2; Fig. S3) argues that wind conditions, particularly wind direction, exert a strong impact on sea surface conditions off Adélie Land, in agreement with several studies at larger spatial scales (Massom et al., 2003, 2009; Smith et al., 2011; Wang et al., 2014; Campagne et al., 2015). Based on PCA analyses between our proxy records and instrumental data, we document the sedimentary response to changes in environmental conditions with a special emphasis on wind fields and wind-induced sea ice variability; therefore, we refine proxies validation at the regional scale (Note S2; Fig. S3; Table S3). Results are summarized and presented in Table 1.

Here, environmental parameters were averaged over the ice-free season (from November to March) to allow a direct comparison of the impact of atmospheric and sea surface conditions on the sedimentary response and, by inference, on the biological surface response. F1 axis, which accounts the highest variance of $18.09 \%$ (Fig. S5), represents sea ice conditions from November to March, as driven by SIC, the length of the sea-ice-free season and the sea ice dynamics (Fig. 4). The easterly wind direction is significant on $\mathrm{F} 1+$ while the southerly wind component is significantly lo-

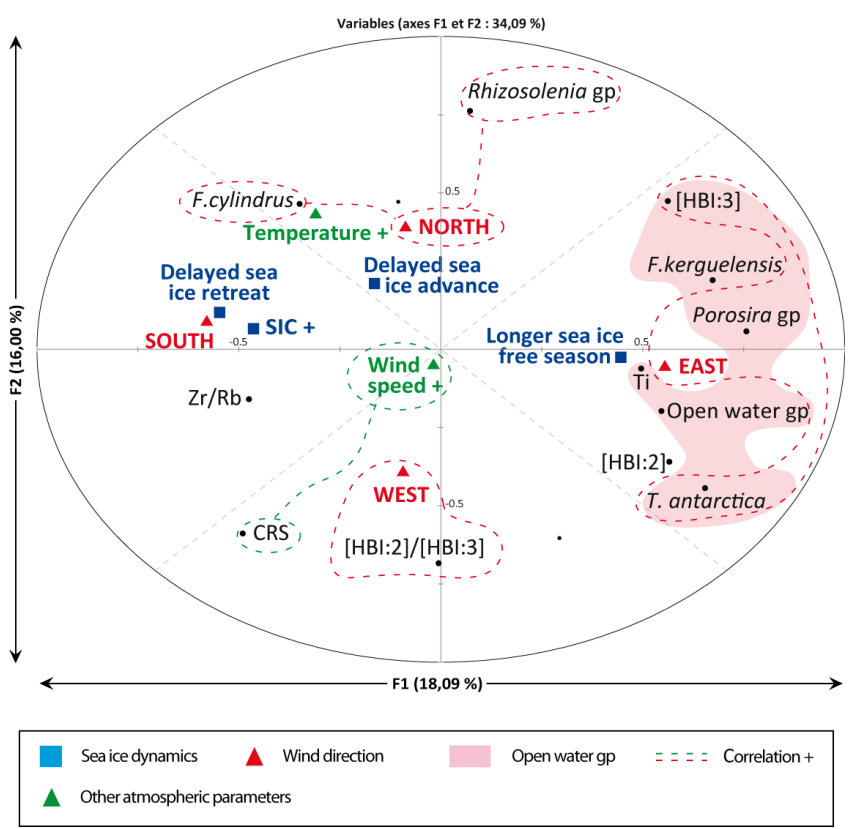

Figure 4. PCA applied to standardized sedimentary data from the DTCI2010 core and meteorological parameters. The yearly standardized sedimentary data represent the ice-free season of the related year. Weather forecast/satellite data were averaged between November and March. F1 axis represents the sea ice conditions linked to the predominant easterly and southerly winds. F2 axis represents the secondary wind directions in the study area, northerly and westerly winds.

cated on F1- (Fig. 4; Table S4), indicating that sea ice conditions and dynamics off Adélie Land are strongly impacted by the dominant wind field. F2 axis accounts for $16 \%$ of the total variance (Fig. S5). Westerly and northerly wind directions are significantly located on F2 - and F2+ respectively, with very low scores on F1 (Fig. 4; Table S4). Increasing wind direction (southerly to westerly winds) or weak onshore (northerly winds) circulation is of cyclonic origin in our study area (Heil et al., 2006; Parish and Bromwich, 2007; Wang et al., 2014). This result suggests that storm forcing on sea ice conditions are represented by the F2 axis. We hereafter present the sedimentary response to the four cases of mean wind fields and wind-induced sea ice conditions identified by our PCA analyses (Note S2; Fig. S3).

\subsubsection{Westerly winds increase spring sea ice conditions}

A dominant westerly wind component originating from enhanced cyclone activity conduces to lower temperatures and wind speed in our data (Heil et al., 2006; Parish and Bromwich, 2007; Massom et al., 2003; 2009; Wang et al., 2014; Note S2). Westerly winds have been observed to decrease the open water fraction, promote pack ice or thinner sea ice lasting longer in spring and delayed sea ice advance in autumn in our study area (Massom et al., 2003; 
Heil et al., 2006; Smith et al., 2011; Wang et al., 2014; Zhai et al., 2015; Note S2). Under such conditions, the sedimentary response shown by the PCA indicates increased content of the [HBI:2] / [HBI:3] ratio, which is significantly correlated with westerly winds (0.398; Table S4) and presents a strong negative relationship with low temperature in our data (Fig. 4). Similar relationships are observed for [HBI:2] (Fig. 4). Our observations agree with the environmental interpretation of these proxies as sea ice and cold environment indicators (Table 1; Note S1). Indeed, it has been suggested recently that relatively high [HBI:2] in surface samples from East Antarctica might be a good indicator of extended (into summer) seasonal sea ice cover, whereas meltwater stratified marginal sea ice environments should be associated with lower [HBI:2] (Smik et al., 2016). Therefore, the occurrence of [HBI:2] in sediments might attest to the presence of overlying heavy pack ice conditions or episodic fast ice presence from spring to summer time in our study area (Table 1).

\subsubsection{Northerly winds increase spring sea ice conditions}

At the Antarctic scale, northerly winds promote early spring sea ice retreat and late autumn sea ice advance (Stammerjohn, et al., 2008). However, northerly winds in our study area have been observed to decrease northward transport of sea ice and increase sea ice duration (Holland et al., 2012; Wang et al., 2014). Our PCA results (Fig. 4) indicate that the northerly wind component is associated with lower wind speeds conducive to delayed sea ice advance at the core site (Note S2), but relationships with SIC and sea ice retreat date are not clear in our data. We here propose that northerly winds have two opposite impacts on sea ice conditions off Adélie Land. Firstly, they tend to increase spring sea ice presence in the area, likely by pushing the offshore pack ice toward the coast or limiting its northward transport. Secondly, they contribute to increase summer melting and delay ice regrowth in autumn by transporting warm air from the north and by enhancing the swell. Under such environmental conditions, the sedimentary response shown by the PCA indicates increasing abundances of the Rhizosolenia gp., [HBI:3] and F. cylindrus, that have high scores on F2+ (Fig. 4). The concomitant presence of sea-ice-related proxies and open ocean proxies indicate a marked seasonal cycle. Fragilariopsis cylindrus displays a strong association with high temperature in our study area, but present a nonsignificant positive relationship with SIC (Table S4). Our results may thus indicate that $F$. cylindrus responds to pack ice presence in spring and subsequent rapid melting (Table 1) as previously evidenced elsewhere (Gersonde and Zielinski, 2000; Armand et al., 2005).

Our results suggest that both $F$. cylindrus and [HBI:2] are associated with longer sea ice duration in spring and summer in our study area (Table 1). However, they respond to different sea ice conditions whereby sea ice dwelling diatoms synthesizing the [HBI:2] have greater affinities with heavy pack ice or fast ice conditions under more westerly winds (colder sea ice) while $F$. cylindrus develops at the pack ice edge and within sea ice meltwater conditions under weak northerly winds (warmer sea ice) (Table 1). This dichotomy may explain that the biomarker record lags behind the diatom record by $\sim 2$ years in core DTCI2010 (Fig. 3a). However, time series studies on the formation, export and burial of HBIs and diatoms are necessary to fully understand this decoupling. We note that [HBI:2] and F. cylindrus present similar trends at decadal to pluri-decadal scales, supporting their use as complementary sea ice indicators for palaeoclimate studies (e.g. Campagne et al., 2015). Regarding the productivity associated with summer time, the presence of [HBI:3], a marker of open-water-related productivity, along with Rhizosolenia gp., an indicator of warmer conditions and of a long diatom productivity season (Note S1), would support the presence of stable sea surface conditions due to low wind speed during summer and of enhanced open water conditions in autumn (Table 1).

\subsubsection{Easterly winds induce open conditions}

A dominant easterly wind component yields earlier sea ice retreat and earlier sea ice advance, lower SIC from November to March and, to some extent, a longer ice-free season in the study area (Fig. 4; Note S2). Easterly winds tend to increase ice advection and icebergs in the area and contribute to building a fast ice buttress over the banks (Massom et al., 2009). Persistence of fast ice promontories during the summer over the Dibble and the DDU banks, can in turn act as a barrier to westward sea ice advection and lead to the establishment of open water conditions over the DDUT, as observed in several locations off East Antarctica (e.g. MGP and Terra Nova Bay polynyas) (Arrigo and van Dijken, 2003; Massom et al., 2001; 2009; Campagne et al., 2015). Similarly in autumn, easterly winds tend to increase ice advection and icebergs in the area, providing favourable conditions for the formation of thick fast ice and buttress earlier in the autumn (Heil et al., 2006). Under such environmental conditions, the PCA indicates that the sedimentary response consists of higher abundances of several proxies strongly intercorrelated on $\mathrm{F} 1+$, T. antarctica, the Porosira gp., F. kerguelensis, [HBI:3] and Ti (red shaded area on Fig. 4; Table S4). The Ti signal is also linked to the northerly wind component (Table S4), suggesting that this proxy is tied to onshore wind circulation and probably responds to a longer ice-free season. Thalassiosira antarctica, Porosira gp., F. kerguelensis and Ti are strongly linked to low SIC over the ice-free season in our study area (Table S4). Similarly, [HBI:3], the Porosira gp. (-0.431; Table S4), F. kerguelensis (-0.360) and $T$. antarctica are strongly associated with earlier open water conditions, and F. kerguelensis is linked to a longer ice-free season. We conclude that the Open Water gp., F. kerguelensis, $\mathrm{Ti}$ and [HBI:3] are associated with long ice-free 
seasons associated with easterly winds, suggesting that these species develop under oligotrophic and stable environments (Table 1). The Porosira gp. and T. antarctica are associated with an earlier sea ice advance in autumn and lower temperature (Table 1; Fig.4; Table S4). These results agree well with ecological preferences of those diatoms, which are considered as biological indicators of early sea ice freezing in autumn (Table 1; Note S1). However, in our study the Porosira gp. is linked to a longer ice-free season than T. antarctica (Fig. 4; Table S4). These results contradict palaeoecological inferences on these species whereas $P$. glacialis has been associated with slightly longer annual sea ice cover relative to T. antarctica (Pike et al., 2009), maybe because these studies did not separate the two varieties of $T$. antarctica.

Our observations support the use of the Open Water gp., $F$. kerguelensis, Ti and [HBI:3] as indicators of the lengthening of ice-free conditions in palaeoclimate studies (Table 1). Our results are generally in line with the known environmental conditions of these proxies occurrence (Table 1; Note S1), as along with Porosira gp. and T. antarctica, these proxies have been attributed to more open conditions in the Mertz Glacier Polynya area during periods with reinforced easterly wind conditions (Campagne et al., 2015). The lengthening of the ice-free season results from early sea ice retreat, probably due to the development of the DDU polynya (Arrigo et al. 2003) during the early spring to summer period. Indeed, the concomitant presence of the Porosira gp. and T. antarctica indicate early sea ice regrowth as a response to an easterly wind field (Table 1) that has been shown to weaken the northward transport of sea ice in the region, thus increasing sea ice conditions in autumn (Massom et al., 2003, 2009). This suggests that $T$. antarctica and the Porosira gp. are good indicators of autumnal sea ice dynamics forced by atmospheric variability.

\subsubsection{Katabatic winds and coastal polynya}

Southerly winds are of katabatic origin in our study area (Wendler et al., 1997; Note S2). A dominant southerly wind component is conducive to a delayed spring sea ice retreat and late autumn freezing, higher SIC from November to March, and to some extent, a shortened ice-free season in the study area (Note S2). Indeed, strong katabatic winds break the fast ice along the coast, leading to enhanced open water conditions and to the formation of a coastal polynya constrained to the coastline (Vaillancourt et al., 2003; Massom et al., 2009; Riaux Gobin et al., 2013). However at the core site, the pack ice would be present due to a reduced fast ice buttress and the increasing northward transport of the pack ice under strong southerly winds (Massom et al., 2009). Under such environmental conditions, the sedimentary response shown by the PCA indicates increasing abundances of the CRS gp. and $\mathrm{Zr} / \mathrm{Rb}$ that are strongly linked to F1- (Fig. 4). Their response to katabatic wind events is probably through the opening of a coastal polynya (Note S2). In addition, al- though the CRS gp. shows no relation with SIC parameters, this group is associated with a strong wind speed $(0.364$; Table $\mathrm{S} 4$ ) over the ice-free season, in agreement with the environmental interpretation of the species (Note S1). In contrast, $\mathrm{Zr} / \mathrm{Rb}$ is closely associated with increasing SIC over the icefree season in addition to a delayed sea ice retreat (Table S4).

Enhanced polynya activity along the coast has been shown to coincide with a deep mixed layer and high Chl a levels (Vaillancourt et al., 2003; Riaux Gobin et al., 2013). Stronger vertical mixing may increase nutrient availability, favouring the rapid development of the Chaetoceros Hyalochaete spp. Spore formation may occur through deep mixing of vegetative cells under the photic zone or nutrient depletion when winds weaken. Northward lateral advection of surface production from the coast to the study area may explain the occurrence of CRS gp. along with more sea ice at the core site. Continuous sea ice formation in the coastal polynya may favour brine production and subsequently stronger bottom currents, leading to the observed $\mathrm{Zr} / \mathrm{Rb}$ high values. However changes in the phase relationship between relative abundances of the CRS gp. and $\mathrm{Zr} / \mathrm{Rb}$ content over the last 40 years argue for periodic decoupling between polynya activity and katabatic winds. We propose that CRS are strongly linked to katabatic wind pulses and rapid stratification/mixing events while $\mathrm{Zr} / \mathrm{Rb}$ is more directly linked to polynya activity (and bottom water velocity) that responds to windy conditions (Table 1). Under southerly winds both high values CRS and $\mathrm{Zr} / \mathrm{Rb}$ are expected while under strong south to easterly winds lower CRS abundances but still high $\mathrm{ZR} / \mathrm{Rb}$ values are expected (Table 1 ).

\section{Conclusions}

Investigation of annual to interannual relationships between diatom communities, diatom-specific biomarkers and major element abundances in connection with meteorological parameters shows that the relevance and use of some proxies (1) may be characteristic of the study area (e.g. CRS gp. assemblage) or (2) differ slightly from previous long-term studies (e.g. F. cylindrus). Indeed, at such a fine scale, the distribution of the sea-ice-related proxies in sediments highlights complex relationships between the biota and sea ice concentration, dynamics, cover structure and origin, constrained by the wind pattern. Our results therefore attest to the importance of the origin and nature of the sea ice in the sedimentary distribution of sea ice proxies. A clear and unambiguous distinction of sea ice type through a finer satellite study in the region (e.g. MODIS satellite imagery) would greatly help to assess and better constrain such relationships. However, we note that the complex interrelations between winds and sea ice should be alleviated at longer timescales when large atmospheric and ocean temperatures changes become preponderant. On the other hand, in our study area, openocean-related proxies seem to be primarily connected to the 
length of the growing season, thus agreeing well with previously published regional-to-large-scale studies. Polynya activity may be inferred from variations in the $\mathrm{Zr} / \mathrm{Rb}$ ratio values. Monitoring the sedimentary signal formation in surface water, its export throughout the water column and burial in deep-sea sediments are necessary to understand the regional behaviour of the proxies commonly constrained via synoptic studies. Other high-resolution and longer timescale reconstructions are required to refine our understanding of the ice-ocean-atmosphere interactions and system feedbacks.

\section{Data availability}

Supplementary core data are available at: https://doi.org/10. 1594/PANGAEA.863075TS1.

\section{The Supplement related to this article is available online at doi:10.5194/bg-13-4205-2016-supplement.}

Author contributions. Xavier Crosta and Guillaume Massé designed the study and Philippine Campagne carried it out. Olivier Ther performed diatom extraction and XRF analyses; Philippine Campagne performed diatom census counts and PCA analyses; Marie Noëlle Houssais extracted daily sea ice concentrations; Sabine Schmid performed ${ }^{210} \mathrm{~Pb}$ analyses and developed the age model of the core; Philippine Campagne prepared the manuscript with contributions from all co-authors.

Acknowledgements. This research was funded by the ERC StG ICEPROXY project (203441), the ANR CLIMICE project and FP7 Past4Future project (243908). The CNRS (Centre National de la Recherche Scientifique) and the FRQNT (Fonds de recherche du Québec - Nature et technologies) provided the student fellowship. The French Polar Institute provided logistical support for sediment and data collection (IPEV projects 452 and 1010). This is ESF PolarClimate HOLOCLIP contribution no. 24 and Past4Future contribution no. 83. The authors thank Johan Etourneau and Emmanuelle Sultan for sample collection. The authors thank Debra Christiansen-Stowe and Julie Sansoulet for administrative assistance.

Edited by: N. Ohkouchi

\section{References}

Adolphs, U. and Wendler, G.: A pilot study on the interactions between katabatic winds and polynyas at the Adelie Coast, eastern Antarctica, Ant. Sci., 7, 307-314, 1995.

Armand, L. K., Crosta, X., Romero, O., and Pichon, J.-J.: The biogeography of major diatom taxa in Southern Ocean sediments: 1. Sea ice related species, Palaeogeogr. Palaeocl., 223, 93-126, 2005.
Arrigo, K. R. and van Dijken, G. L.: Phytoplankton dynamics within 37 Antarctic coastal polynya systems, J. Geophys. Res., 108, C8, doi:10.1029/2002JC001739, 2003.

Beans, C., Hecq, J. H., Koubbi, P., Vallet, C., Wright, S., and Goffart, A.: A study of the diatomdominated microplankton summer assemblages in coastal waters from Terre Adélie to the Mertz Glacier, East Antarctica (139_E-145_E), Pol. Bio., 31, 11011117, 2008.

Campagne, P., Crosta, X., Houssais, M. N., Swingedouw, D., Schmidt, S., Martin, A., Devred, E., Capo, S., Marieu, V., Closset, I., and Masse, G.: Glacial ice and atmospheric forcing on the Mertz Glacier Polynya over the past 250 years, Nat. Comm., 6, 6642, doi:10.1038/ncomms7642, 2015.

Cavalieri, D. J., St. Germain, K., and Swift, C. T.: Reduction of weather effects in the calculation of sea ice concentration with the DMSP SSM/I, J. Glaciol., 41, 455-464, 1995.

Collins, L. G., Allen, C. S., Pike, J., Hodgson, D. A., Weckström, K., and Massé, G.: Evaluating highly branched isoprenoid (HBI) biomarkers as a novel Antarctic sea-ice proxy in deep ocean glacial age sediments, Quaternary Sci. Rev., 79, 87-98, 2013.

Crosta, X. and Koc, N.: Diatoms: From micropaleontology to isotope geochemistry, in: Methods in Late Cenozoic Paleoceanography, edited by: Hilaire-Marcel, C. and de Vernal, A., Elsevier, Amsterdam, the Netherlands, 327-369, 2007.

Crosta, X., Sturm, A., Armand, L., and Pichon, J. J.: Late Quaternary sea ice history in the Indian sector of the Southern Ocean as recorded by diatom assemblages, Mar. Micropaleontol., 50, 209-223, 2004.

Crosta, X., Romero, O., Armand, L. K., and Pichon, J.-J.: The biogeography of major diatom taxa in Southern Ocean sediments: 2. Open ocean related species, Palaeogeogr. Palaeocl., 223, 66-92, 2005.

Defelice, D. R. and Wise, S. W.: Surface lithofacies, biofaces, and diatom diversity patterns as models for delineation of climatic change in the southeast Atlantic Ocean, Mar. Micropaleontol., 6, 29-70, 1981.

Denis, D., Crosta, X., Zaragosi, S., Romero, O., Martin, B., and Mas, V.: Seasonal and subseasonal climate changes recorded in laminated diatom ooze sediments, Adelie Land, East Antarctica, Holocene, 16, 1137-1147, 2006.

Dinniman, M. S., Klinck, J. M., and Hofmann, E. E.: Sensitivity of circumpolar deep water transport and ice shelf basal melt along the west Antarctic Peninsula to changes in the winds, Amer. Meteor. Soc., 25, 4799-4816, 2012.

Escutia, C. and Party, S. S.: Integrated Ocean drilling Program Expedition 318 Preliminary Report, Integrated Ocean drilling Program Management International, Inc. for the Integrated Ocean Drilling Program, 101 pp., 2010.

Escutia, C., Warnke, D., Acton, G. D., Barcena, A., Burckle, L., Canals, M., and Frazee, C. S.: Sediment distribution and sedimentary processes across the Antarctic Wilkes Land margin during the Quaternary, Deep-Sea Res. Pt. II, 50, 1481-1508, 2003.

Fleury, S., Martinez, P., Crosta, X., Charlier, K., Billy, I., Hanquiez, V., and Schneider, R. R.: Pervasive multidecadal variations in productivity within the Peruvian Upwelling System over the last millennium, Quaternary Sci. Rev., 125, 78-90, 2015.

Gersonde, R. and Zielinski, U.: The reconstruction of late Quaternary Antarctic sea-ice distribution - the use of diatoms as a proxy for sea-ice, Palaeogeogr. Palaeocl., 162, 263-286, 2000. 
Giles, A. B., Massom, R. A., and Lytle, V. I.: Fast ice distribution in East Antarctica during 1997 and 1999 determined using RADARSAT data, J. Geophys. Res.-Ocean., 113, C02S14, doi:10.1029/2007JC004139, 2008.

Hasle, G. R.: An analysis of the phytoplankton of the Pacific Southern Ocean: abundance, composition, and distribution during the Brategg Expedition, 1947-1948, Univ.-Forl, 1969.

Heil, P.: Atmospheric conditions and fast ice at Davis, East Antarctica: A case study, J. Geophys. Res.-Ocean., 111, C05009, doi:10.1029/2005JC002904, 2006.

Holland, P. R. and Kwok, R.: Wind-driven trends in Antarctic seaice drift, Nat. Geosci., 5, 872-875, 2012.

Jacobs, S.: Bottom water production and its links with the thermohaline circulation, Ant. Sci., 16, 427-437, 2004.

Kang, S.-H. and Fryxell, G. A.: Fragilariopsis cylindrus (Grunow) Krieger: The most abundant diatom in water column assemblages of Antarctic marginal ice edge zones, Pol. Biol., 12, 609-627, 1992.

König-Langlo, G., King, J. C., and Pettré, P.: Climatology of the three coastal Antarctic stations Dumont d'Urville, Neumayer and Halley, J. Geophys. Res., 103, 10 935-10 946, 1998.

Lacarra, M., Houssais, M. N., Herbaut, C., Sultan, E., and Beauverger, M.: Dense shelf water production in the Adélie Depression 2004-2012: Impact of the Mertz glacier calving, J. Geophys. Res., 119, 5203-5220, 2014.

Leventer, A.: Modern distribution of diatoms in sediments from the Georges V coast, Antarctica, Mar. Micropaleontol., 19, 315-332, 1992.

Leventer, A., Dunbar, R. B., and DeMaster, D. J.: Diatom evidence for late Holocene climatic events in Granite Harbor, Antarctica, Paleoceanography, 8, 373-386, 1993.

Maddison, E. J., Pike, J., Leventer, A., Dunbar, R., Brachfeld, S., Domack, E. W., Manley, P., and McClennen, C.: Post-glacial seasonal diatom record of the Mertz Glacier Polynya, East Antarctica, Mar. Micropaleontol., 60, 66-88, 2006.

Maddison, E. J., Pike, J., and Dunbar, R.: Seasonally laminated diatom-rich sediments from $\mathrm{Du}$ mont d'Urville Trough, East Antarctic Margin: Late-Holocene Neoglacial sea-ice conditions, Holocene, 22, 857-875, 2012.

Massé, G., Belt, S. T., Crosta, X., Schmidt, S., Snape, I., Thomas, D. N., and Rowland, S. J.: Highly branched isoprenoids as proxies for variable sea ice conditions in the Southern Ocean, Ant. Sci., 23, 487-498, 2011.

Massom, R. A., Harris, P. T., Michael, K. J., and Potter, M. J.: The distribution of formative processes of latent heat polynyas in East Antarctica, Ann. Glaciol., 27, 420-426, 1998.

Massom, R. A., Eicken, H., Haas, C., Jeffries, M. O., Drinkwater, M. R., Sturm, M., Worby, A. P., Wu, X., Lytle, V. I., Ushio, S., Morris, K., Reid., P. A., Warren, S. G., and Allison, I.: Snow on Antarctic sea ice, Rev. Geophys., 39, 413-445, 2001.

Massom, R. A., Jacka, K., Pook, M. J., Fowler, C., Adams, N., and Bindoff, N.: An anomalous late season change in the regional sea ice regime in the vicinity of the Mertz Glacier Polynya, East Antarctica, J. Geophys. Res.-Ocean., 108, 3212, doi:10.1029/2002JC001354, 2003.

Massom, R. A., Hill, K., Barbraud, C., Adams, N., Ancel, A., Emmerson, L., and Pook, M. J.: Fast ice distribution in Adélie Land, East Antarctica: interannual variability and implications for em- peror penguins Aptenodytes forsteri, Mar. Ecol.-Prog. Ser., 374 243-257, 2009.

Meredith, M. P.: Oceanography: Replenishing the abyss, Nat. Geosci., 6, 166-167, 2013.

Migeon, S., Weber, O., Faugères, J.-C., and Saint-Paul, J.: SCOPIX: a new X-ray imaging system for core analysis, Geo.-Mar. Lett., 18, 251-255, 1999.

Parish, T. R. and Bromwich, D. H.: Reexamination of the nearsurface airflow over the Antarctic continent and implications on atmospheric circulations at high southern latitudes, Mon. Weather Rev., 135, 1961-1973, 2007.

Périard, C. and Pettré, P.: Some aspects of the climatology of Dumont d'Urville, adélie land, Antarctica, Int. J. Climatol., 13, 313328, 1993.

Pike, J., Crosta, X., Maddison, E. J., Stickley, C. E., Denis, D., Barbara, L., and Renssen, H.: Observations on the relationship between the Antarctic coastal diatoms Thalassiosira antarctica Comber and Porosira glacialis (Grunow) Jørgensen and sea ice concentrations during the late Quaternary, Mar. Micropaleontol., 73, 14-25, 2009.

Presti, M., De Santis, L., Busetti, M., and Harris, P. T.: Late Pleistocene and Holocene sed imentation on the George V Continental Shelf, East Antarctica, Deep-Sea Res. Pt. II, 50, 1441-1461, 2003.

Rathburn, A. E., Pichon, J. J., Ayress, M. A., and De Deckker, P.: Microfossil and stable isotope evidence for changes in Late Holocene palaeoproductivity and palaeoceanographic conditions in the Prydz Bay region of Antarctica, Palaeogeog. Palaeoecol., 131, 231-248, 1997.

Riaux-Gobin, C., Romero, O. E., Coste, M., and Galzin, R.: A new Cocconeis (Bacillario- phyceae) from Moorea Island, Society Archipelago, South Pacific Ocean with distinctive valvocopula morphology and linking system, Bot. Mar., 56, 339-356, 2013.

Rintoul, S. R.: On the origin and influence of Adélie land bottom water, in: Ocean, Ice, and Atmosphere: Interactions at the Antarctic Continental Margin, edited by: Jacobs, S. and Weiss, R., American Geophysical Union, Washington, DC, 75, 151$171,1998$.

Robbins, J. A. and Edgington, D. N.: Determination of recent sedimentation rates in Lake Michigan using Pb-210 and Cs-137, Geochim. Cosmochim. Ac., 39, 285-304, 1975.

Sambrotto, R. N., Matsuda, A., Vaillancourt, R., Brown, M., Langdon, C., Jacobs, S. S., and Measures, C.: Summer plankton production and nutrient consumption patterns in the Mertz Glacier Region of East Antarctica, Deep-Sea Res. Pt. II, 50, 1393-1414, 2003.

Schmidt, S. and De Deckker, P.: Present-day sedimentation rates on the southern and southeastern Australian continental margins, Aust. J. Earth Sci., 62, 143-150, 2015.

Sinninghé Damsté, J. S., Muyzer, G., Abbas, B., Rampen, S. W., Massé, G., Allard, W. G., Belt, S. T., Robert, J. M., Rowland, S. J., Moldowan, J. M., Barbanti, S. M., Fago, F. J., Denisevich, P., Dahl, J., Trindade, L. A. F., and Schouten, S.: The rise of the Rhizosolenoid diatoms, Science, 304, 584-587, 2004.

Smik, L., Belt, S. T., Lieser, J. L., Armand, L. K., and Leventer, A.: Distributions of highly branched isoprenoid alkenes and other algal lipids in surface waters from East Antarctica: Further insights for biomarker-based paleo sea-ice reconstruction, Organ. Geochem., 95, 71-80, 2016. 
Smith, M. B., Labat, J. P., Fraser, A. D., Massom, R. A., and Koubbi, P.: A GIS approach to estimating interannual variability of sea ice concentration in the Dumont d'Urville Sea near Terre Adélie from 2003 to 2009, Pol. Sci., 5, 104-117, 2011.

Stammerjohn, S. E., Martinson, D. G., Smith, R. C., Yuan, X., and Rind, D.: Trends in Antarctic annual sea ice retreat and advance and their relation to El Niño-Southern Oscillation and Southern Annular Mode variability, J. Geophys. Res., 113, C03S90, doi:10.1029/2007JC004269, 2008.

Vaillancourt, R. D., Sambrotto, R. N., Green, S., and Matsuda, A.: Phytoplankton biomass and photosynthetic competency in the summertime Mertz Glacier Region of East Antarctica, Deep-Sea Res. Pt. II, 50, 1415-1440, 2003.

Wang, Z., Turner, J., Sun, B., Li, B., and Liu, C.: Cyclone-induced rapid creation of extreme Antarctic sea ice conditions, Scientific Reports, 4, 5317, doi:10.1038/srep05317, 2014.

Wendler, G., Stearns, C., Weidner, G., Dargaud, G., and Parish, T.: On the extraordinary kata batic winds of Adélie Land, J. Geophys. Res.-Atmos., 102, 4463-4474, 1997.

Williams, G. D. and Bindoff, N. L.: Wintertime oceanography of the Adélie depression, Deep-Sea Res. Pt. II, 50, 1373-1392, 2003.
Williams, G. D., Bindoff, N. L., Marsland, S. J., and Rintoul, S. R.: Formation and export of dense shelf water from the Adélie Depression, East Antarctica, J. Geophys. Res., 113, C04039, doi:10.1029/2007JC004346, 2008.

Zhai, M., Li, X., Hui, F., Cheng, X., Heil, P., Zhao, T., and Liu, J.: Sea-ice conditions in the Adélie Depression, Antarctica, during besetment of the icebreaker RV Xuelong, Ann. Glaciol., 56, 160166, 2015.

Zielinski, U. and Gersonde, R.: Diatom distribution in Southern Ocean surface sediments (At lantic sector): Implications for paleoenvironmental reconstructions, Palaeogeogr. Palaeocl., 129, 213-250, 1997. 